\title{
Erratum: BMP type I receptor inhibition reduces heterotopic ossification
}

Paul B Yu, Donna Y Deng, Carol S Lai, Charles C Hong, Gregory D Cuny, Mary L Bouxsein, Deborah W Hong, Patrick M McManus, Takenobu Katagiri, Chetana Sachidanandan, Nobuhiro Kamiya, Tomokazu Fukuda, Yuji Mishina, Randall T Peterson \& Kenneth D Bloch Nat. Med. 14, 1363-1369 (2008); published online 30 November 2008; corrected after print 4 December 2008

In the version of this article initially published, the title included a misspelling-'heterotropic' should have been 'heterotopic'. Additionally, the fourth and fifth sentences of the abstract were incorrectly worded and have been corrected to state more clearly the role of Ad.Cre. These changes do not affect the scientific content of the text. The errors have been corrected in the HTML and PDF versions of the article.

\section{Corrigendum: Eradication of acute promyelocytic leukemia-initiating cells through PML-RARA degradation}

Rihab Nasr, Marie-Claude Guillemin, Omar Ferhi, Hassan Soilihi, Laurent Peres, Caroline Berthier, Philippe Rousselot, Macarena RobledoSarmiento, Valérie Lallemand-Breitenbach, Bernard Gourmel, Dominique Vitoux, Pier Paolo Pandolfi, Cécile Rochette-Egly, Jun Zhu \& Hugues de Thé

Nat. Med. 14, 1333-1342 (2008); published online 23 November 2008; corrected after print 7 January 2009

In the version of this article initially published, the $x$-axis title of the right-hand graph in the 'Day 2' part of Figure 1f was incorrect. The title should read 'Time to death in secondary transplants (d)'. The error has been corrected in the HTML and PDF versions of the article. 